DOI: $10.17951 / 1 r p .2021 .40 .3 .157-177$

\author{
MAgdalena WóJCiK \\ Maria Curie-Skłodowska University, Lublin, Poland \\ ORCID - 0000-0002-2836-8742
}

\title{
GRAPHOMOTOR SKILLS OF STUDENTS WITH MILD INTELLECTUAL DISABILITY
}

Introduction: The development of graphomotor skills in children in primary school age is a difficult and long process, and its disturbance leads to serious problems not only with the process of writing but also disrupts the purely academical learning. For students with mild intellectual disability, writing is a more difficult challenge due to cognitive and perceptual-motor limitations. Research Aim: The aim of this research was to diagnose the graphomotor skills of students with mild intellectual disability attending mainstream primary schools. Method: The research was carried out on a sample of 30 students with mild intellectual disability, attending grades II and III of mainstream primary schools. The SOSG Graphomotor Performance Scale by Aneta Domagała and Urszula Mirecka (2017) was used to assess the graphomotor skills of the studied students. This scale is a diagnostic tool used to evaluate both the technique of graphomotor activity and the evaluation of the products of graphomotor activity. Results: The research showed disturbances among students with intellectual disability in holding a writing tool, sitting posture while writing, the pace of graphomotor activity and the associated high degree of fatigue, incorrect pressure of the writing tool and line stability, disturbed proportions within letters and letter-like characters, size and inclination of letters and letter-like characters in the structure of the pattern, slant and size of the script and letter-like patterns, incorrect spacing between words/constituent units of letter-like patterns, difficulty in keeping the letter/patterns in the ruling and the location of the text and patterns in the horizontal and vertical arrangement. Conclusions: The presented results indicate great graphomotor difficulties of students with mild intellectual disability. These difficulties, based on neurophysiological knowledge, suggest the basis of this type of graphomotor errors. That is why a thorough individual diagnosis and appropriately adjusted therapeutic interactions are so important and in the first place should be based on exercises involving the stimulation of gross motor skills, integration of tonic reflexes, regulation of muscle tone, exercises to improve praxia in the field of gross and fine motor skills, while not neglecting perceptual skills and eye-hand coordination.

Keywords: writing, graphomotor skills, mild intellectual disability 


\section{INTRODUCTION}

Writing is a complex process in which three basic elements can be distinguished: psychological, physiological and motor. The first element - the psychological one concerns the sound, visual and motor analysis, i.e. the appropriate auditory image of sounds and the corresponding graphic shapes of letters and their connections, together with the subordination of motor images. In other words, the child must have an auditory image of the equivalent of a letter (sound) in order to connect the letter and the word as a whole, and imagine the direction in which the letter is drawn. The second element - the physiology of the writing process - is based on complex nervous agitations, their integration in the cerebral cortex and the hand motor apparatus. As a result of the integration of nerve agitations, appropriate auditory, visual and motor representations may arise in the writer in the cerebral cortex, as well as in the subcortical nuclei. Mobility control in the form of visual control and kinesthetic sensations plays an important role in this process. The motor element consists of coordinated movements of the hand - arm, forearm, wrist and fingers, as well as technical aspects of writing, such as correct writing posture, correct sitting posture, hand layout, eye-to-page distance, holding the writing tool and the features of the writing tool itself (Wróbel, 1979; as cited in Zakrzewska, 2005, p. 17; Rocławska-Daniluk, 2009; Piotrowska-Madej, Żychowicz, 2018).

In the motor aspect, the development of writing skills depends not only on the efficiency of large motor skills (especially coordination of movements, the ability to cross the midline of the body) and correct kinesthesia, i.e. awareness of the position of the body in space, appropriate muscle tension, proper stabilization of the joints directly and indirectly related to the act of writing. It also depends on the correct perception of form and space, planning of movement and motor memory, sequencing, integration of tonic reflexes, postural reactions and somatosensory perception - thanks to all these factors, movement patterns are mastered, which leads to the automation of the process writing (Karga, 2008; Domagała, Mirecka, 2017 , p. 9). In order to master complex graphomotor skills, the child should reach an appropriate level of perceptual-motor development adequate to its developmental age.

Graphomotor skills are assessed by evaluating various skills in writing such as writing speed, fluidity of movement, letter arrangements, spacing between letters, and the pressure used to write. In particular, handwriting legibility and writing speed are key factors in assessing the acquisition of graphomotor skills. Handwriting legibility refers to readability, which is affected by inconsistencies of letter size and spacing as well as inaccurate letter form. Although writing speed alone is insufficient in determining whether one is proficient in writing, writing speed gradually increases with age as writing abilities improve. 
In addition to handwriting legibility and writing speed, writing pressure is another factor of handwriting evaluation. Generally, children who are unskilled at writing write more largely, irregularly, and slowly than adults who are proficient in writing (No, Choi, 2021).

As a consequence, the child does not keep up with the class, gets tired quickly and discourages. With time, he develops an aversion to all kinds of graphic arts (drawing, painting and writing). This, in turn, is a symptom of secondary (emotional and motivational) disorders that overlap with the primary disorders (motor skills and eye-hand coordination) (Bogdanowicz, 2009). Children who find handwriting more difficult and effortful may become fatigued more quickly than their peers, and may be less able to demonstrate their knowledge and comprehension through written assignments (Donica, Goins, Wagner, 2013).

\section{WRITING AND GRAPHOMOTOR SKILLS IN PEOPLE WITH MILD INTELLECTUAL DISABILITY}

The diverse picture of writing difficulties of students with mild intellectual disability depends primarily on the type and degree of the student's disorder, but also depends on the stage of teaching. Students with mild intellectual disability show difficulties in all aspects of writing skills - listening and writing, writing from memory, rewriting, independent writing, spelling.

In the initial period of acquiring writing and reading skills, the child reproduces letters, so first of all, must correctly perceive their shapes (visual perception), remember them (memory), associate them with appropriate sounds (auditory perception), thinking, and then write them down (motor skills, visual coordination). With each of these functions and activities, intellectually disabled children may have difficulty in reading and writing - forgetting and confusing letters, adding, rearranging and omitting letters, syllables and words. The pace of writing and the pace of acquiring this skill is very slow. Pupils with mild intellectual disability in the older grades - once they have sufficiently practiced the most elementary skills necessary for writing and reading - face various difficulties in mastering these techniques: grammar, spelling, lexical and purely technical difficulties. The act of writing is performed with the participation of the speech organs - so students often help themselves by saying silently (or even loudly) individual sounds. Correct articulation is a prerequisite for a proper writing process, though not the only one, of course. Speech defects (lisp, reranging, nasalisation, etc.) occurring in students are also reflected in the writing. Both in writing and reading, there is a persistent tendency to repeat sounds, syllables and even whole words and sentences multiple 
times, and to prolong the duration of the articulation movement, which results in the tendency to perseveration (Tkaczyk, 1997; Kaczorowska-Bray, 2017).

A diagnosis of an intellectual disability often involves specific motor impairments, which are likely to contribute to deficits in handwriting skills. Children with an intellectual disability demonstrated poor co-ordination of fine motor movement and tended to use a tighter or stronger grip than was required when using a precision grip (Grindle et al., 2017).

In terms of mastering these skills, children with mild intellectual disability usually reach the initial stage of using them in a functional manner. Most of them limit themselves to mastering the ability to recognize and use graphic and acousticphonic symbols and to associate them with extra-linguistic content (Maurer, 1991).

Written statements of students with intellectual disabilities are characterized by a low level of graphs. Frequent occurrence of misshapen, uneven, unsteady letters in children's texts and the lack of connections between them usually results from low precision of hand movements and lower level of eye-hand coordination. In this group, there is a lower level of motor development, impairment of individual motor characteristics, especially the precision of movements and simultaneous movements, and the most numerous graphic errors include the construction of letters, combining letters in a word, handwriting proportionality and writing. Using punctuation marks and capital letters in the right places also causes a lot of trouble. Most often, students do not think about the correctness of the notation, focusing on the writing activity itself, which for many of them is a great mental and physical effort. The handwriting often does not fit in line with the ruling, it is unsteady, illegible. It is especially difficult for students with mental disability to write sentences correctly, formulate their own thoughts, and build longer, independent written statements (Kaczorowska-Bray, 2017).

\section{DIAGNOSIS OF WRITING SKILLS}

In diagnostic practice, to assess the degree of mastery of writing skills, three types of tests are used - rewriting, listening and writing, and writing from memory. These tests are designed to identify typical errors, assess the technique and pace of writing and the graphic level of the handwriting. Typically, three criteria are taken into account when assessing the level of handwriting: - legibility, understood as the number of easily identifiable letters,

- writing, relating to the degree of fluency of the writing movements and the freedom to carry them out,

- aesthetics (Rocławska-Daniluk, 2009, p. 26). 
For functional writing, legibility is the most important criterion. It depends on how the letters are written and how they are combined. In order for the script to be legible, there must be no graphic mistakes in it. These include:

1. Design mistakes - inaccuracy in recreating the shape of the letter, wrong proportion in its structure and inconsistency of the elements it consists of. Among the design mistakes, we can distinguish letter shape failure, as well as line distortion.

2. Mistakes in combining letters in words - no joining and incorrect joining of letters in words.

3. Proportionality mistakes - no spaces between words, not keeping the proportions of letters in words and uneven height of letters.

4. Mistakes of uneven writing direction - change of direction while writing (Piotrowska-Madej, Żychowicz, 2018).

\section{THE PROBLEM AND PURPOSE OF THE RESEARCH}

The main research problem was the answer to the question: "What is the level of graphomotor skills in children with mild intellectual disability?".

In connection with the problem formulated in this way, the aim of the research was to diagnose the graphomotor skills of students with mild intellectual disability attending grades II and III in mainstream primary schools.

\section{RESEARCH METHOD AND CHARACTERISTICS OF THE SAMPLE}

The SOSG Graphomotor Skills Assessment Scale by Aneta Domagała and Urszula Mirecka (2017) was used to assess the graphomotor skills of the studied students. This scale is a diagnostic tool used to evaluate both the technique of graphomotor activity and the evaluation of the products of graphomotor activity. The Observation Protocol and the Letter and Similar Patterns Assessment Card are used for this, respectively. The evaluation of the products of graphomotor activity is based on the obtained handwriting samples and samples of letter-like patterns and refers to the activities of writing and drafting-drawing activities, therefore, each of these skills is separately assessed and analyzed. Attempts to reproduce letter-like patterns are made on sheets without lines, and attempts to rewrite - on lines, which allows to reveal fundamentally different phenomena, both at the level of symptoms and causes of difficulties in writing observed in the examined person.

The test includes 2 diagnostic tests: 
Test 1 consists in drawing letter-like patterns on a piece of paper without ruling.

Test 2 is rewriting the text on a piece of paper with ruled lines.

In the second test, the text was selected adequately to the level of school education, and the diagnostic attempts are preceded by an appropriate instruction. Therefore, the following text was used for the studied groups:

\section{Przyjaciele}

"Franuś i jego pies Łatek lubili się ścigać. Goniąc po wąskiej ścieżce, powpadali na siebie. Ojej! Teraz chłopiec głaszcze psa, a ten liże jego ręce”.

Translation:

\section{Friends}

"Franuś and his dog Łatek liked to race. As they chased down the narrow path, they collided with each other. Oh my! Now the boy is petting the dog who is licking his hands".

The study was conducted on 30 male and female students with mild intellectual disability, with no additional disabilities or disorders, confirmed by a decision about the need for special education. The selection of the group was based on purposive sampling technique. The study was conducted with the consent of the parents. The surveyed students attended grades II and III of mainstream primary schools in the cities of Lublin voivodeship. Seven girls and eight boys attended grade II, and six girls and nine boys attended grade III.

Grade I students were excluded from the study due to the fact that the aim of the study was to analyze the graphic image of the writing, and taking into account the program of integrated early school education, children at this stage of education are only introduced to the world of writing.

The obtained results were compared with the percentage distribution of the results in the same categories in non-disabled students compiled by the authors of the diagnostic tool, presented in the manual "SOSG Graphomotor Skills Assessment Scale" by Domagała and Mirecka (2017).

\section{DATA ANALYSIS PROCEDURE}

Samples for the assessment of motor skills were obtained by rewriting texts that were constantly available during the study. Compared to the calligraphy study, which is based on the analysis of texts dictated and recorded by ear, rewriting does not 
slow down the rate of writing due to reflecting on the spelling, and this is not an aspect of the study. In addition, the student has the opportunity to avoid spelling mistakes, which will allow more likely diagnostic accuracy, recognize mistakes as graphical, and not spelling (in the case of correcting the spelling - correcting, blurring letters, etc.). Due to the involvement of specific functions, it also allows to link the observed disorders with their determinants in the kinesthetic and motor sphere, visual perception and eye-hand coordination (Domagała, Mirecka, 2010).

\section{DISCUSSION OF RESEARCH RESULTS}

\section{ANALYSIS OF THE RESULTS OF THE SCALE FOR ASSESSMENT \\ OF GRAPHOMOTOR PERFORMANCE}

\section{Data analysis from the Observation Protocol}

The observation protocol included 5 main areas concerning the study of both the reproduction of letter-like patterns on a piece of paper without ruling, as well as rewriting the demonstrated text on a piece of paper with ruling. The protocol includes the determination of the leading (dominant) hand, the way of holding the graphic tool, the position of the piece of paper against the edge of the table, sitting posture of the student and his pace of work (Domagała, Mirecka, 2017).

\section{THE LEADING HAND}

In this study, the choice of the right or left hand is indicated as normative behavior, however, it is not tantamount to the statement of right- or left-handedness, and the diagnosis of the correct model of laterality in the child.

The right hand was the leading hand for all children in both classes. None of the children was using their right and left hands interchangeably.

\section{THE WAY OF HOLDING THE GRAPHIC TOOL}

The way students with mild intellectual disabilities hold the writing tool includes both the type of grip used and the place where the tool is held. The results are presented in Table 1. 
Table 1.

The way of holding a graphic tool - own elaboration

\begin{tabular}{|c|c|c|c|c|c|c|}
\hline \multirow[b]{2}{*}{$\begin{array}{l}\text { The way of holding } \\
\text { the graphic tool }\end{array}$} & \multicolumn{2}{|c|}{ Grade II } & \multicolumn{2}{|c|}{ Grade III } & \multicolumn{2}{|c|}{ In total } \\
\hline & 品 & $\hat{\overbrace{}}_{\infty}^{\infty}{ }_{\infty}^{\infty}$ & 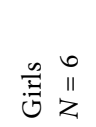 & $\hat{\sigma}_{\infty}^{\infty} \ddot{z}$ & 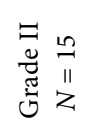 & 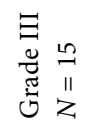 \\
\hline Type of grip & & & & & & \\
\hline $\begin{array}{l}\text { 1. Tool resting on the middle finger, } \\
\text { held by the thumb and forefinger }\end{array}$ & $14.28 \%$ & 0 & $33.33 \%$ & $11.11 \%$ & $6.67 \%$ & $20 \%$ \\
\hline $\begin{array}{l}\text { 2. Holding the tool with three fingers } \\
\text { with the wrong arrangement of the } \\
\text { thumb, index and middle finger or } \\
\text { other finger selection }\end{array}$ & $71.44 \%$ & $50 \%$ & $66.67 \%$ & $55.56 \%$ & $60 \%$ & $66.67 \%$ \\
\hline 3. Holding the tool with two fingers & 0 & 0 & 0 & 0 & 0 & 0 \\
\hline 4. Holding the tool with four fingers & $14.28 \%$ & $50 \%$ & 0 & $33.33 \%$ & $33.33 \%$ & $13.33 \%$ \\
\hline 5. Holding the tool with five fingers & 0 & 0 & 0 & 0 & 0 & 0 \\
\hline 6. Grip with the whole hand & 0 & 0 & 0 & 0 & 0 & 0 \\
\hline Fingers distance & & & & & & \\
\hline 1. Distance $1.5-2.5 \mathrm{~cm}$ & $42.86 \%$ & $12.5 \%$ & $50 \%$ & $22.22 \%$ & $26.66 \%$ & $33.33 \%$ \\
\hline 2. Distance too short & $57.14 \%$ & $87.5 \%$ & $50 \%$ & $77.78 \%$ & $73.33 \%$ & $66.67 \%$ \\
\hline 3. Distance too far & 0 & 0 & 0 & 0 & 0 & 0 \\
\hline
\end{tabular}

The graphic tool was held correctly (based on the middle finger, pressed by the thumb and guided by the index finger) by only $6.67 \%$ of grade II students and $20 \%$ of grade III students. $60 \%$ of students in grades II and $66.67 \%$ in grades III - held the tool with three fingers with the wrong arrangement of the thumb, index and middle finger or with a different choice of fingers (e.g. holding the tool between the thumb, index and ring finger or holding the tool with the sides of the fingers). Four fingers to hold the tool were used by $33.33 \%$ of second graders and $13.33 \%$ of third graders. None of the examined children held the tool with two or five fingers or grasped it with the whole hand.

The correct distance between the fingers and the writing tip was presented by $26.67 \%$ of the 2 nd grade students and $33.33 \%$ of the 3 rd grade students, the remaining part of the students from each grade kept the distance from the tip of the writing tool too small $-73.33 \%$ of the second grade and $66.67 \%$ of the third grade, respectively.

There are also differences between genders in favor of girls' skills, but it should be remembered that these groups are not numerous and it is difficult to apply these results to a larger population.

Comparing these results with the percentage distribution of the same criteria in non-disabled students prepared by the authors of the tool - lower skills in this 
respect are visible in children with intellectual disabilities (the tool was correctly held by $64.30 \%$ of class II students and $53.85 \%$ of class III students, with three fingers). The tool was held with three fingers with the wrong arrangement of the thumb, index and middle finger or with a different choice of fingers by $30.05 \%$ of second-graders and $40.45 \%$ of third-graders, with four fingers - in grade II - $4.15 \%$ of students and in third grade $-4.65 \%$, did not hold a tool with their whole hand, and $0.85 \%$ of second-graders and no one from the group of 3rd grade students).

The differences are also visible in the distance at which the tool is held $-63.05 \%$ of non-disabled students in grade II and $62.55 \%$ of students in grade III keep the appropriate distance from the end of the graphic tool.

\section{PLACING THE PAGE IN RELATION TO THE EDGE OF THE TABLE}

This category includes information on the sheet on which the student writes and draws patterns and its location relative to the edge of the table - the results of the study group are presented in Table 2 .

Table 2.

Placement of a sheet of paper in relation to the edge of the table

\begin{tabular}{|c|c|c|c|c|c|c|}
\hline \multirow[b]{2}{*}{$\begin{array}{l}\text { Placing the page } \\
\text { in relation to the edge of the table }\end{array}$} & \multicolumn{2}{|c|}{ Grade II } & \multicolumn{2}{|c|}{ Grade III } & \multicolumn{2}{|c|}{ In total } \\
\hline & 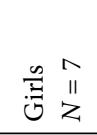 & $\begin{array}{ll}\infty & \infty \\
\hat{o}^{n} & \| \\
\infty & \end{array}$ & \begin{tabular}{ll}
0 \\
$:$ & 11 \\
\hdashline
\end{tabular} & 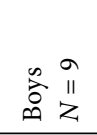 & 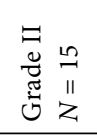 & 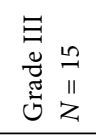 \\
\hline 1. A sheet of paper arranged perpendicularly & $71.42 \%$ & $62.5 \%$ & $83.33 \%$ & $55.56 \%$ & $73.33 \%$ & $66.67 \%$ \\
\hline 2. Laid at a slight angle & $14.28 \%$ & 0 & $16.67 \%$ & $11.11 \%$ & $6.67 \%$ & $13.33 \%$ \\
\hline 3. Variable correct arrangement of the page & 0 & 0 & 0 & 0 & 0 & 0 \\
\hline 4. The page is oblique to the right & 0 & 0 & 0 & 0 & 0 & 0 \\
\hline 5. The sheet of paper oblique to the left side & $14.28 \%$ & $37.5 \%$ & 0 & $33.33 \%$ & $20 \%$ & $20 \%$ \\
\hline 6. Variable oblique arrangement of the page & 0 & 0 & 0 & 0 & 0 & 0 \\
\hline
\end{tabular}

Analyzing the results, it can be seen that both - the second and third graders with intellectual disabilities - obtained high percentages in the correct positioning of the sheet of paper in relation to the table (as many as $73.33 \%$ of students in grades II and $66.67 \%$ of students in grades III had a perpendicularly arranged sheet in relation to the edge of the table - there is also a visible difference in the results obtained by girls and boys of both classes in favor of girls). Moreover, $6.67 \%$ of second-graders and $13.33 \%$ of third-graders changed the layout of the page at a slight angle, while maintaining the desired regularity. All the examined 
children had the right leading hand, therefore, any difficulties were manifested in the fact that the page was turned to the left $(20 \%$ of students in grades 2 and the same number from grades 3 ).

Also in this category, girls from both classes achieved visibly better results.

The results obtained by students with a mild intellectual disability are similar to those obtained by non-disabled students $(76.45 \%$ of second-graders and $77.3 \%$ of third-graders).

\section{SITTING POSTURE}

This category allows to indicate the body postures adopted by the student while performing graphomotor activities, which is presented in detail in Table 3.

Table 3.

Sitting posture during graphomotor activities

\begin{tabular}{|c|c|c|c|c|c|c|}
\hline \multirow[b]{2}{*}{ Student's sitting posture } & \multicolumn{2}{|c|}{ Grade II } & \multicolumn{2}{|c|}{ Grade III } & \multicolumn{2}{|c|}{ In total } \\
\hline & $\stackrel{n}{I}$ & $\hat{\overbrace{}}_{\infty}^{\infty}{ }_{\infty}^{\infty}$ & \begin{tabular}{ll}
0 \\
$\vdots$ \\
\hdashline & 11 \\
0
\end{tabular} & $\hat{\sigma}_{0}^{\infty} \ddot{z}$ & 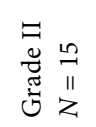 & 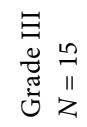 \\
\hline Student's position on the chair & & & & & & \\
\hline $\begin{array}{l}\text { 1. A stable position on the chair, a short } \\
\text { distance from the table }\end{array}$ & $42.86 \%$ & $25 \%$ & $50 \%$ & $22.22 \%$ & $33.33 \%$ & $33.33 \%$ \\
\hline 2. He/She is sitting on the edge of the chair & 0 & $12.5 \%$ & 0 & $22.22 \%$ & $6.67 \%$ & $13.33 \%$ \\
\hline 3. Feet/foot unsupported on the floor & $14.28 \%$ & $12.5 \%$ & $16.67 \%$ & $11.11 \%$ & $13.33 \%$ & $13.33 \%$ \\
\hline 4. Excessive body movements & $14.28 \%$ & $37.5 \%$ & 0 & $33.33 \%$ & $26.67 \%$ & $20 \%$ \\
\hline 5. He/She rests his/her torso on the table & $28.58 \%$ & $12.5 \%$ & $16.67 \%$ & $22.22 \%$ & $20 \%$ & $20 \%$ \\
\hline 6. Excessive distance from the table & 0 & 0 & 0 & 0 & 0 & 0 \\
\hline Torso and head position & & & & & & \\
\hline $\begin{array}{l}\text { 1. The torso is straight or slightly tilted, } \\
\text { without yawing or twisting to the side }\end{array}$ & $14.28 \%$ & 0 & $16.67 \%$ & $11.11 \%$ & $6.67 \%$ & $13.33 \%$ \\
\hline 2. The head is in line with the torso & $14.28 \%$ & 0 & $16.67 \%$ & 0 & $6.67 \%$ & $6.67 \%$ \\
\hline 3. Torso excessively tilted & $14.28 \%$ & $25 \%$ & $16.67 \%$ & $22.22 \%$ & $20 \%$ & $20 \%$ \\
\hline 4. Torso tilted back & 0 & 0 & 0 & 0 & 0 & 0 \\
\hline 5. Torso tilted to the side or twisted & 0 & $37.5 \%$ & $16.67 \%$ & $22.22 \%$ & $20 \%$ & $20 \%$ \\
\hline 6. Head excessively tilted & $28.58 \%$ & $12.5 \%$ & $33.33 \%$ & $22.22 \%$ & $20 \%$ & $26.67 \%$ \\
\hline 7. Head tilted to the side or twisted & $28.58 \%$ & $25 \%$ & 0 & $22.22 \%$ & $26.67 \%$ & $13.33 \%$ \\
\hline
\end{tabular}

The same number of $2 \mathrm{nd}$ and 3 rd grade students (33.33\% in both groups) could maintain a stable position on the chair, not far from the table, $6.67 \%$ of 2 nd grade students and $13.33 \%$ 3rd grade students were seated on the edge of the chair. The 
same number of second- and third-graders had no support on the floor $(13.33 \%$ in both groups). Excessive body movements were observed in $26.67 \%$ of grade II students and $20 \%$ of grade III students, and boys showed more hyperactivity in both age groups. On the other hand, $20 \%$ of students from both classes leaned on the table.

These are visibly lower results than those obtained by non-disabled students (65.75\% of non-disabled students in the 2 nd grade and $62.7 \%$ of the 3 rd grade students had a stable position).

\section{THE PACE OF WORK}

This category, as the name suggests, includes information on the student's pace of work while performing graphomotor activities and includes both time data from the measurement carried out during diagnostic trials and data from the qualitative observation of the student's writing and pattern drawing rate - these data are presented in Table 4.

Table 4.

Pace of performing graphomotor activities

\begin{tabular}{|c|c|c|c|c|c|c|}
\hline \multirow[b]{2}{*}{$\begin{array}{l}\text { The pace of performing } \\
\text { graphomotor activities }\end{array}$} & \multicolumn{2}{|c|}{ Grade II } & \multicolumn{2}{|c|}{ Grade III } & \multicolumn{2}{|c|}{ In total } \\
\hline & 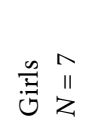 & $\begin{array}{c}\infty \\
\hat{o}_{0}^{\infty} \\
\infty \\
\infty\end{array}$ & \begin{tabular}{ll}
0 \\
$:$ & 11 \\
\hdashline & $Z$
\end{tabular} & 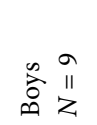 & 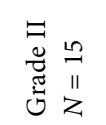 & 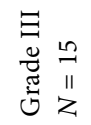 \\
\hline 1. The student works regularly & $14.28 \%$ & 0 & $16.67 \%$ & $11.11 \%$ & $6.67 \%$ & $13.33 \%$ \\
\hline 2. The student works with frequent breaks & $42.85 \%$ & $37.5 \%$ & $33.33 \%$ & $22.22 \%$ & $40 \%$ & $26.67 \%$ \\
\hline $\begin{array}{l}\text { 3. The student works with clear signs of } \\
\text { fatigue }\end{array}$ & $28.57 \%$ & $25 \%$ & $33.33 \%$ & $11.11 \%$ & $26.67 \%$ & $20 \%$ \\
\hline 4. The student slows down & $14.28 \%$ & 0 & $16.67 \%$ & $11.11 \%$ & $6.67 \%$ & $13.33 \%$ \\
\hline 5. The student works with long breaks & 0 & $12.5 \%$ & 0 & $11.11 \%$ & $6.67 \%$ & $6.67 \%$ \\
\hline 6. The student accelerates & 0 & $25 \%$ & 0 & $33.33 \%$ & $13.33 \%$ & $20 \%$ \\
\hline $\begin{array}{l}\text { 1. Time of reproduction of patterns on a piece } \\
\text { of paper without ruling } \\
\text { 2. Time to rewrite the text on a sheet with } \\
\text { ruled lines }\end{array}$ & $\begin{array}{l}6 \text { min., } \\
58 \text { sec. } \\
9 \text { min., } \\
6 \mathrm{sec} .\end{array}$ & $\begin{array}{l}7 \text { min., } \\
21 \mathrm{sec} . \\
11 \mathrm{~min} . \\
8 \mathrm{sec} .\end{array}$ & $\begin{array}{l}5 \text { min., } \\
51 \text { sec. } \\
6 \text { min., } \\
28 \text { sec. }\end{array}$ & $\begin{array}{l}5 \text { min., } \\
31 \mathrm{sec} . \\
6 \mathrm{~min} . \\
9 \mathrm{sec} .\end{array}$ & $\begin{array}{l}7 \text { min., } \\
15 \text { sec. } \\
10 \text { min., } \\
12 \mathrm{sec} .\end{array}$ & $\begin{array}{l}5 \mathrm{~min} . \\
41 \mathrm{sec} . \\
6 \mathrm{~min} . \\
18 \mathrm{sec} .\end{array}$ \\
\hline
\end{tabular}

As the results in Table 4 show - only $6.67 \%$ of grade II students and $13.33 \%$ of the surveyed grade III students work in a regular manner. $40 \%$ of second-graders and $26.67 \%$ of third-graders work with frequent breaks. Marked fatigue, such as interrupting writing and straightening the hand, moving fingers, massaging the hand to relieve 
pain or fatigue, is represented by $26.67 \%$ of students in grades II and $20 \%$ of students in grades III. $6.67 \%$ of second-graders and $13.33 \%$ of third-graders slow down while writing, and $13.33 \%$ of students in grades II and $20 \%$ in grades III (all boys) speed up. $6.67 \%$ of students in both age groups work with significantly extended breaks.

These results are much more unfavorable in comparison with the results of non-disabled students, as in this group as many as $70.95 \%$ of students in grades II and $73.15 \%$ of students in grades III work regularly.

The pace of work in terms of the time of reproducing patterns on a piece of paper without lines, compared to the established norms for gender and class, indicates the average results of girls and boys attending grades II. On the other hand, girls from class III obtained a low work pace score, and boys - average. However, it should be borne in mind that boys often speeded up drawing patterns at the expense of the quality of work.

The pace of work in the scope of rewriting the text on a piece of paper with ruling, both for girls and boys from grades II and III, is at a low level.

\section{DATA ANALYSIS OF THE HANDWRITING RATING SCALE}

AND LETTER-LIKE PATTERNS

The analysis of the products of graphomotor activities - the reproduction of letter-like patterns and the prescribed text - includes 6 categories. In this section, both handwriting samples are assessed against the different criteria included in each category.

\section{Line}

1. Pressure of the writing tool

In the case of reproduction of letter-like patterns, the normative result for this criterion was obtained by $26.67 \%$ of students in grades II and $40 \%$ of students in grades III - this means that the pressure of the writing tool is correct for them. In $6.67 \%$ of students in grades II and III, the trace of handwriting is too weak and indistinct, while in $26.67 \%$ of second-graders and $20 \%$ of third-graders - the trace is too strong. On the other hand, in $40 \%$ of the surveyed students in grades II and $33.33 \%$ of students in grades III - the clarity of the trace is variable.

These results are lower than those of non-disabled students $(60.3 \%$ have correct pressure, $5.5 \%$ - too weak, $13 \%$ - too strong, and $22.9 \%$ - variable).

The analysis of the text written on a sheet with ruling allowed to determine that only $13.33 \%$ of students in grades II and $26.67 \%$ of students in grades III rewrite the text with appropriate pressure. $6.67 \%$ of students of both groups show too weak 
pressure, $33.33 \%$ of students in grade II and $26.67 \%$ in grade III have the pressure too strong, and $46.67 \%$ of the surveyed second-graders and $40 \%$ of third-graders have a variable pressure, which in combination with non-disabled students is also less favorable for students with intellectual disabilities $(58.5 \%$ - correct pressure, $12.3 \%$ - weak pressure, $8.7 \%$ - too strong, and $22.9 \%$ - variable pressure).

\section{Line stability}

In the case of reproduction of letter-like patterns, in $26.67 \%$ of students in grades II and $33.33 \%$ in grades III the line is fixed and certain. In $13.33 \%$ of second-graders and $6.67 \%$ of third-graders the line is shaky. In $26.67 \%$ of children in grades II and $20 \%$ of children in grades III show unevenness and curvature of the line, $33.33 \%$ of the second- and third-graders draw bold, retouched lines, and in $13.33 \%$ of the surveyed children from grades II and $6.67 \%$ from grades III, there are uncontrolled line extensions, especially at the end of the pattern.

When rewriting the text on a piece of paper with ruling - $20 \%$ of second-graders and $26.67 \%$ of third-graders lead the correct line. $20 \%$ of students in grades II and $6.67 \%$ of students in grades III have a shaking line, unevenness and curvature of the line are visible in $46.67 \%$ of the surveyed students in grades II and $40 \%$ in grades III. 33.33\% of children in grades II and III thicken and retouch the lines, and in $20 \%$ of students in grades II and $6.67 \%$ of students in grades III, uncontrolled line extensions are noticed, especially at the end of expressions.

These results are less favorable in comparison with the results of non-disabled students $(41.3 \%$ of fixed and sure lines in letter-like characters and $60.1 \%$ in rewriting text in ruling).

\section{Letter / letter-like symbol}

1. The form of a letter/letter-like symbol

The correct form and aesthetics of both letter-like characters and text in the ruling were obtained by only $6.67 \%$ of third-grade students. $66.67 \%$ of the secondgrade students and $53.33 \%$ of third-graders had distortions in the form of signs (deformation of lines, circles, sharp angles instead of arcs). $40 \%$ of second-grade students and $33.33 \%$ of third-grade students have letterform distortion. In $40 \%$ of students in grades II and $33.33 \%$ of students in grades III, irregularities in the assembly of the components of signs were observed, and in $46.67 \%$ and $33.33 \%$, respectively, there were negligent letters and irregularities in the assembly of the elements of letters. In $33.33 \%$ of second-grade students and $6.67 \%$ of third-grade students, corrections and deletions were visible, and in the case of letters, corrections and deletions related to the letter form were visible in $33.33 \%$ of students in grades II and $26.67 \%$ in grades III. 
These results in comparison with the research results on non-disabled children are relatively similar in most of the subcategories $(12.5 \%$ - correct form of signs and $25.2 \%$ - of letters, $56.1 \%$ - distorted characters and $37.9 \%$ - of letters, $30.7 \%$ - incorrect anastomoses characters and $37.7 \%$ - of letters, corrections and deletions are $35.6 \%$ in letter-like characters, and $27.7 \%$ in letters).

2. Proportions within a letter / letter-like symbol

The proportions within letter-like signs in $26.67 \%$ of the second-graders and $33.33 \%$ of third-graders are correct, and in the area of letters $-13.33 \%$ and $26.67 \%$, respectively (the authors of the tool indicate a result of $38.3 \%$ in non-disabled children), $73.33 \%$ in grades II and $66.67 \%$ in grades III the proportion of signs is incorrect, and the proportion of letters $-86.67 \%$ in grades II and $73.33 \%$ in grades III (59.8\% in children without disability).

III. A letter in a word / a letter-like symbol in the pattern structure

1. Size of the letters in words / letter-like symbols in the pattern structure

$6.67 \%$ of the students in grades II and $20 \%$ in grades III have a constant size of letter-like symbols and $6.67 \%$ and $26.67 \%$ - respectively in both groups - of a constant size of letters. $93.33 \%$ of children in class II and $80 \%$ of children in class III have a variable size of letter-like symbols in the pattern structure. In $13.33 \%$ of students in grades II and $6.67 \%$ in grades III, too small letters may be observed, disproportionate to the letters in a word, and $80 \%$ of students in grades II and III write too large letters. These results show a negative view of this skill in students with intellectual disabilities - in case of non-disabled students' writing skills, the constant size of the symbols is $36.9 \%$, and the letters are as high as $66.7 \%$.

2. Slant of letters in words / letter-like symbols in the pattern structure

Letters-like symbols in the pattern structure and letters in the ruling appear without slanting in only $6.67 \%$ of students in grades II and $15.33 \%$ in grades III, which means that in as many as $93.33 \%$ of students in grade II and $86.67 \%$ of the ones in grade III, there are changes in the inclination of letter-like signs in the structure of the pattern and changes in the inclination of letters (there are less such difficulties in non-disabled children $-66.1 \%$ of students draw letter-like symbols without slanting and $72 \%$ of children do not show any looseness in the inclination of the letters).

3. Combinations of letters in words / letter-like symbols in a pattern structure

Correctly combines symbols in the pattern structure referred to $40 \%$ of secondgraders and $53.33 \%$ of third-graders. In $33.33 \%$ of students from grade II and $26.67 \%$ from grade III, the symbols are separated from each other. In $26.67 \%$ of children 
attending grade II and $20 \%$ of those in grade III, the signs touch each other, they are stuck on - these results are similar to the results in case of non-disabled students $(49.7 \%$ of children connect the symbols correctly, $23.9 \%$ draw the symbols separated from each other, and in $31.5 \%$ of them symbols are touching each other).

On the other hand, when analyzing the text written in the ruling line, it correctly combines letters in words in $13.33 \%$ of second-graders with intellectual disability and $26.67 \%$ of third-graders. In $66.67 \%$ of students in grades II and $20 \%$ in grades III, letters are separated, in $6.67 \%$ of students in grade III, letters touch or overlap. Inaccurate connections are seen in $13.33 \%$ of second- and $20 \%$ of third-grade students, and elongated connections are seen in $6.67 \%$ of secondgraders and $20 \%$ of third-graders. These results differ from those obtained by nondisabled students $-38.7 \%$ of them correctly connect letters, $24.6 \%$ write exploded letters, and $12.2 \%$ write letters touching them together, sticking one to the other.

IV. Writing text / letter-like patterns

1. Tilt of the script / letter-like patterns

Patterns without tilting or with a constant direction are drawn by $53.33 \%$ of second-graders and $66.67 \%$ of third-graders, letters without tilting are written by $20 \%$ of children in II grades and $40 \%$ in III grades. $13.33 \%$ of second-grade students and $6.67 \%$ of third-grade students show excessive skew of patterns, making their recognition difficult, and excessive skewing of patterns, respectively, $20 \%$ and $13.33 \%$ of students in the surveyed grades. The changing direction of the slope of the patterns is visible in $33.33 \%$ of students in grades II and $26.67 \%$ of students in grades III, and in the case of writing it is $60 \%$ and $46.67 \%$, respectively. These results are much weaker than those obtained by non-disabled students, where $69 \%$ of them redraw patterns perpendicularly, and as many as $86.1 \%$ have writing without slanting.

\section{Size of the writing / letter-like patterns}

Among the second-graders, $13.33 \%$ redraw the pattern of the correct size in the horizontal and vertical dimensions, and among the third-graders, $26.67 \%$ of students have this skill. The patterns vary in size have $86.67 \%$ of the students in II grade and $73.33 \%$ in III grade. These values are slightly lower than in the case of non-disabled children ( $28.7 \%$ correct size of the formula, 70.1 variable value).

When analyzing the letters in the ruled line, $6.67 \%$ of children with intellectual disability in II grade and $20 \%$ in III grade have the correct size. The rest of children $(93.33 \%$ in grades II and $80 \%$ in grades III) have their handwriting too big. There is, therefore, a significant difference in comparison with the results of non-disabled children (64.1\% of children have a letter of the correct size). 


\section{Organization of the verse}

1. Spaces between words / constituent units of letter-like patterns

The correct distance between the constituent units of letter-like patterns (a space with a width equal to 1-2 lowercase letters) is maintained by $20 \%$ of students in grade II and $40 \%$ of students in grade III, and between words - by $6.67 \%$ and $26.67 \%$ of students in grades II and III, respectively. $40 \%$ of students with intellectual disability in grades II and $33.33 \%$ in grades III retain too small a distance between the components, and in the case of the distance between words - too small a distance is kept by $46.67 \%$ of students in grades II and $33.33 \%$ of students in grades III. In $13.33 \%$ of children from grades II and $6.67 \%$ of children from grades III, the component units of the formulas touch each other, and in the case of words - they touch each other in $20 \%$ of second-graders and $13.33 \%$ of third-graders. In $26.67 \%$ of second-graders and $20 \%$ of third-graders, there is too much distance between the components of formulas and between words (for comparison, $53.8 \%$ of non-disabled children maintain the correct distance between the components of formulas, and $67.3 \%$ between words).

\section{Keeping the writing / patterns in line}

In only $6.67 \%$ of students with mild intellectual disability in grades II and $13.33 \%$ in grades III, the pattern is written horizontally. For $33.33 \%$ of grade II students and $26.67 \%$ of grade III students, the line of the verse is ascending, and for $40 \%$ of students in grades II and III, the line of the verse is falling. Differences in the level between the components of the formulas are visible only in $6.67 \%$ of second-graders (similar results are found in non-disabled children: $14.8 \%$ - horizontal recording, $44.8 \%$ - falling line, 39\% - rising).

When analyzing texts in lineage $-13.3 \%$ of second-graders and $33.33 \%$ of third-graders have the notation correctly positioned in the line, $40 \%$ of students in grades II and $26.67 \%$ of students in grades III place the writing above the line, and $46.67 \%$ of students in second grades and $40 \%$ of the third grades show letters and words crossing the line (including the entry under the line), which in combination with the results of non-disabled students shows a lower level of fitness in this area of students with intellectual disabilities (59.1\% of non-disabled students correctly position the text in the line).

\section{Organization of the page}

1. Placing the text / patterns in the horizontal position

Only $13.33 \%$ of second-graders and $20 \%$ of third-graders keep a record with regular margins and spaces, the remaining students in grades II and III make uneven spacing from the edge of the page ( $40 \%$ and $53.33 \%$ - a result similar to 
the result of non-disabled students - 47.5\%), too large margins (33.33\% and $20 \%)$ or write without any space from the edge of the page (13.33\% and $6.67 \%)$, which brings this result closer to the results of non-disabled students (11.3\% regular margins, $66.3 \%$ unequal spacing, $19.1 \%$ no spacing, $4.1 \%$ margins too large).

$13.33 \%$ of second-graders and $26.67 \%$ of third-graders have the ability to write a text in line ruling with regular margins, $40 \%$ of students in grades II and $46.67 \%$ of students in grades III have irregular margins, whereas too large in $26.66 \%$ of second-graders and $20 \%$ of third-graders. Many students $(60 \%$ in grades II and $46.67 \%$ in grades III) have a problem with centering the title.

2. Placing the text / patterns in the vertical position

$13.33 \%$ of children from grades II and $33.33 \%$ of children from grades III keep the distance from the top of the page in drawing patterns without ruling (the result in case of non-disabled students is $44.8 \%$ ). The overwhelming majority (46.67\% and $33.33 \%)$ of students in grades II and III do too little line spacing, and $13.33 \%$ of both grades make the line spacing too large (37.3\% of non-disabled students do too little line spacing and only $5 \%$ do the line spacing too large). In the case of text in the line ruling, the notation in the following lines from the top of the page is made by $53.33 \%$ of students in grades II and by $73.33 \%$ in grades III (73.1\% of non-disabled students). On the other hand, the incorrect choice of lines is presented by $33.33 \%$ of intellectually disabled students in grades II and $20 \%$ in grades III - and these results are lower than in the case of non-disabled children (10.4\%).

\section{CONCLUSIONS}

The research results presented in the article indicate a lower level of graphomotor skills of students with mild intellectual disability in comparison to no-disabled students. Significant differences to the disadvantage of students with intellectual disabilities are visible in most of the areas of the Scale for Assessment of Graphomotor Performance (the way of holding the graphic tool, sitting posture, the pace of work). Only in one category - placing the page in relation to the edge of the table - results are similar to those of non-disabled students. Data analysis of the Handwriting Rating Scale and letter-like patterns also shows much lower results of students with mild intellectual disability in terms of:

- pressure of the writing tool,

- line stability,

- proportion of signs and letters, 
- size of the letters in words / letter-like symbols in the pattern structure,

- slant of letters in words / letter-like symbols in the pattern structure,

- correct combinations of letters in words / letter-like symbols in a pattern structure,

- tilt of the script / letter-like patterns,

- size of the writing / letter-like patterns,

- spaces between words / constituent units of letter-like patterns,

- placing the text / patterns in the vertical position.

All these difficulties may result from the specificity of psychomotor functioning of children with intellectual disability. Cognitive and perceptual-motor functioning of students at this stage of education, resulting directly from global intellectual delay, contributes to difficulties in diagnosed aspects.

Problems with producing a written text are the most common of intellectual and communicative difficulties. To understand the writing difficulties, teachers must identify and document the ways in which problems manifest themselves (Swärd, Karlsson, 2020).

At first, it is necessary to identify the underlying cause of graphomotor difficulties, which may result from improper distribution of muscle tone, motor planning disorders in the area of gross and fine motor skills, failure to extinguish tonic neck reflexes, coordination disorders or the development of postural reactions and movement dissociation (Bartkiewicz, Giczewska, 2012).

Failure to take into account the global specificity of the child's perceptualmotor functioning may not only fail to improve the child's manual functioning, but, what is worse, aggravate and deepen the difficulties.

The diagnosis of manual functioning should, therefore, take into account:

1. General image of the child (the way the child moves, muscular tension, posture, positions in which he stays / plays / learns).

2. Posture and movement patterns (head control, shoulder positioning and torso control, symmetry / asymmetry, contractures and deformities, mobility of the upper limbs, associated reactions / compassion, unquenched reflexes).

3. Functions of the upper limbs (support, elbow extension, way of reaching, type of grip, the ability to loosen the grip, movement habits - sucking fingers, tapping on the ground, etc., the possibility of dissociating movements).

4. Dexterity of the hand / manipulation (does the toy play with purpose specific manipulation, does it perform precise movements of fingers and hands, quality of grip, dissociation of fingers).

5. Graphomotor skills (how to grasp the tool, analysis of the writing style) (Bartkiewicz, Giczewska, 2012). 
Therefore, when looking at the results obtained in the field of graphomotor performance, each diagnostician and therapist must be aware of the causes of individual difficulties, because only this will allow for effective work and tangible results, because the greatest mistake a therapist can make is to develop a therapeutic program based only on the results, end products in the form of the products of the child's labor.

The presented research results suggest many difficulties that could lead to this type of graphomotor errors - therefore, in the first place, the therapy should be based on exercises that take into account the stimulation of gross motor skills, especially the motor skills of the shoulder girdle, arms, elbow and wrist mobility, integration of tonic reflexes, in particular asymmetrical tonic neck reflex, regulation of muscle tone, exercises to improve praxia in the field of gross and fine motor skills, not forgetting, at the same time, perceptual skills and eye-hand coordination. Such full protection of the child's sensorimotor needs will allow for faster and more effective implementation of the intended therapeutic goals.

\section{RESEARCH LIMITATIONS}

The research was carried out on a group of 30 students with mild intellectual disability, half of whom attended the second grade and the other half attended the third grade. A relatively small group of children did not allow for statistical analysis and comparison of the results with the entire population of students with mild intellectual disability, but it creates a picture of difficulties and challenges in the field of graphomotor skills that this group may present. Therefore, further analyzes on a larger population and comparative studies between the sexes, as well as among other disabilities, are advisable.

\section{REFERENCES}

Bartkiewicz, W., Giczewska, A. (2012). Terapia ręki (nieopublikowane materiały szkoleniowe).

Bogdanowicz, M. (2009). Przygotowanie do nauki pisania. Ćwiczenia grafomotoryczne według Hany Tymichovej. Gdańsk: Harmonia.

Donica, D., Goins, A., Wagner, L. (2013). Effectiveness of Handwriting Readiness Programs on Postural Control, Hand Control, and Letter and Number Formation in Head Start Classrooms. Journal of Occupational Therapy Schools \& Early Intervention, 6(2), 81-93. https://doi.org/10.1080/19411243.2013.810938 
Domagała, A., Mirecka, U. (2010). Grafomotoryka a kształtowanie się sprawności ortograficznych. Problemy w edukacji szkolnej. Annales UMCS sectio FF Philologiae, XXVIII(1), 99-111.

Domagała, A., Mirecka, U. (2017). Skala oceny sprawności grafomotorycznych SOSG. Gdańsk: PTPiP.

Grindle, C., Cianfaglione, R., Corbel, L., Goyen, E. (2017). Teaching Handwriting Skills to Children with Intellectual Disabilities Using an Adapted Handwriting Programme: Handwriting Without Tears. Support for Learning, 32(4), 313-336. https://doi.org/10.1111/1467-9604.12178

Kaczorowska-Bray, K. (2017). Umiejętność pisania i czytania w grupie osób z niepełnosprawnością intelektualną. In: K. Kaczorowska-Bray. Kompetencja i sprawność językowa dzieci z niepełnosprawnościa intelektualna $w$ stopniu znacznym, umiarkowanym i lekkim (pp. 398-341). Gdańsk: UG.

Karga, M. (2008). Neurobiologiczne podstawy procesów integracji sensorycznej i podstawowa ich ocena (nieopublikowane materiały szkoleniowe).

Maurer, A (1991). Terapia trudności w nauce czytania i pisania u dzieci upośledzonych umysłowo. Kraków: WSP.

No, B., Choi, N. (2021). Differences in Graphomotor Skills by the Writing Medium and Children's Gender. Education Sciences, 11(4), 162. https://doi.org/10.3390/ educsci11040162

Piotrowska-Madej, K., Żychowicz, A. (2018). Smart Hand Model. Diagnoza i terapia ręki u dzieci. Gdańsk: Harmonia

Rocławska-Daniluk, M. (2009). Czytanie i pisanie. Gdańsk: UG.

Swärd, A.K., Karlsson, A. (2020). Students with Intellectual Disability Learn How to Write with Motivation and Joy. Psychology Research, 10(11), 423-437. https://doi. org/10.17265/2159-5542/2020.11.001

Tkaczyk, G. (1997). Metodyka nauczania $i$ wychowania początkowego $w$ szkole specjalnej. Lublin: UMCS.

Zakrzewska, B. (2005). Trudności w czytaniu i pisaniu. Modele ćwiczeń. Warszawa: WSiP.

\section{SPRAWNOŚĆ GRAFOMOTORYCZNA UCZNIÓW}

\section{Z NIEPEŁNOSPRAWNOŚCIĄ INTELEKTUALNĄ W STOPNIU LEKKIM}

Wprowadzenie: Rozwój umiejętności grafomotorycznych dzieci w wieku szkolnym jest procesem trudnym i długotrwałym, a jego zakłócenie prowadzi do poważnych problemów nie tylko związanych z samym procesem pisania, ale także zakłóca czysto akademickie możliwości uczenia się. Dla uczniów z lekką niepełnosprawnością intelektualną pisanie jest trudniejszym 
wyzwaniem ze względu na ograniczenia poznawcze i percepcyjno-motoryczne. Cel badań: Celem badań była diagnoza sprawności grafomotorycznej uczniów z lekką niepełnosprawnością intelektualną uczęszczających do szkół podstawowych ogólnodostępnych. Metoda badań: Badaniami objęto 30 uczniów z niepełnosprawnością intelektualną w stopniu lekkim, uczęszczających do klas II i III ogólnodostępnych szkół podstawowych. Do oceny sprawności grafomotorycznej badanych uczniów zastosowano Skalę oceny sprawności grafomotorycznych SOSG autorstwa Anety Domagały i Urszuli Mireckiej (2017). Skala ta jest narzędziem diagnostycznym służącym do oceny zarówno techniki czynności grafomotorycznych, jak i oceny wytworów czynności grafomotorycznych. Wyniki: Badania wykazały u dzieci z niepełnosprawnością intelektualną zaburzenia w zakresie trzymania narzędzia pisarskiego, postawie siedzącej podczas pisania, tempem wykonywania czynności grafomotorycznych i związanym z tym dużym stopniem męczliwości, nieprawidłowym naciskiem narzędzia pisarskiego i stabilnością linii, zaburzeniami proporcji w obrębie liter i znaków literopodobnych, wielkością i pochyleniem liter i znaków literopodobnych w strukturze wzoru, pochylenia i wielkości pisma i wzorów literopodobnych, nieprawidłowych odstępów między wyrazami/jednostkami składowymi wzorów literopodobnych, trudnością w utrzymaniu pisma/wzorów w liniaturze oraz usytuowania tekstu i wzorów w układzie poziomym i pionowym. Wnioski: Zaprezentowane wyniki wskazują na duże trudności grafomotoryczne uczniów z lekką niepełnosprawnością intelektualną. Trudności te, na podstawie wiedzy neurofizjologicznej, sugerują podłoże tego typu błędów grafomotorycznych. Dlatego tak ważna jest wnikliwa diagnoza indywidualna i odpowiedno dostosowane oddziaływania terapeutyczne, które w pierwszej kolejności powinny oprzeć się na ćwiczeniach uwzględniających stymulację dużej motoryki, integrację odruchów tonicznych, regulację napięcia mięśniowego, ćwiczenia usprawniające praksję w zakresie dużej i małej motoryki, nie pomijając jednocześnie umiejętności percepcyjnych i koordynacji wzrokowo-ruchowej.

Słowa kluczowe: pisanie, sprawność grafomotoryczna, lekka niepełnosprawność intelektualna 